ADAM MONIUSZKO

http:/orcid.org/0000-0002-7924-669X

Uniwersytet Warszawski

\title{
Iura Masoviae Terrestria: o edycji i perspektywach jej kontynuacji
}

\author{
Abstract \\ Jura Masoviae Terrestria: Concerning the Work Itself, and Some Perspectives on \\ Its Continuation
}

The present paper focuses on Iura Masoviae Terrestria - an unfinished collection of sources for Masovian law. Work on the volume started back in the latter half of the $20^{\text {th }}$ century. Back in 1956 , Professor Jakub Sawicki obtained financial support from the Polish Academy of Sciences [PAN] to produce the publication. These funds allowed him to assemble a project team and begin research in the archives. The main goal of the project was to publish all general individual public acts of Masovian law from a period beginning in the $13^{\text {th }}$ century through 1577 , i.e. up to the introduction of Polish law in the former Duchy of Masovia. Despite an advanced level of preparation, financial support for the project was withheld in 1958, and progress on its preparation was stopped for a decade. Work was resumed in 1969 with plans for publishing the sources of Masovian law in five volumes, the last with indexes and translation into Polish of the most important Latin acts of the Masovian law. Finally, the first three volumes were published in 1972-1974. Due to health problems and ultimately the passing of Prof. Sawicki, the fourth volume, containing the acts from the 1541-1577 period was never published. Materials for its completion are preserved in Prof. Sawicki's papers in PAN archives. They are to a great extent ready for publishing, although some additional research seems inevitable. The current paper presents perspectives for completing the fourth volume, as well as for possible continuation of the completion of Iura Masoviae Terrestria.

Keywords: Masovian law, edition of legal sources, Jakub Sawicki, Polish historiography after 1945, Iura Masoviae Terrestria

Słowa kluczowe: Prawo mazowieckie, edytorstwo źródeł historii prawa, Jakub Sawicki, historiografia polska po 1945 r., Iura Masoviae Terrestria

Wydanie pomników prawa mazowieckiego budziło zainteresowanie badaczy już w wieku XIX. Część z nich znalazła się w Ius Polonicum Jana Wincentego BandtkieStężyńskiego i pierwszym tomie Starodawnych prawa polskiego pomników wydanych 
przez Antoniego Zygmunta Helcla․ Potrzebę całościowej krytycznej ich edycji w ramach przygotowywanej serii wydawniczej Corpus Iuris Polonici dostrzegał Oswald Balzer ${ }^{2}$, częściowo zresztą - choć poza samą serią - zamierzenie to zrealizował ${ }^{3}$. Pomysł kontynuacji wielkiego dzieła Balzera i wydania korpusu źródeł prawa mazowieckiego powrócił w połowie lat 50. ubiegłego stulecia w działalności Komisji Wydawnictw Źródłowych Instytutu Nauk Prawnych PAN. Kierowanie przygotowaniem wydawnictwa zaproponowano Jakubowi Sawickiemu, profesorowi katedry historii państwa i prawa polskiego na Wydziale Prawa i Administracji Uniwersytetu Warszawskiego. Wprawdzie nie zajmował się on wcześniej ustrojem i prawem mazowieckim ${ }^{4}$, lecz - dzięki edycji statutów synodalnych, ukazujących się w monumentalnej serii Concilia Poloniae - zdobył uznanie jako bardzo dobry wydawca źródeł prawa średniowiecznego. Wybór ten był interesujący także z tego powodu, że Jakub Sawicki nie cieszył się w okresie stalinowskim względami nowej władzy ${ }^{5}$. Odsunięto go od prac komisji reformy prawa patentowego (której wcześniej przewodniczył), szykanowano na macierzystym wydziale (m.in. pozbawiano możliwości prowadzenia zajęć, de facto odebrano samodzielną katedrę historii ustroju i prawa polskiego); stał się także obiektem zainteresowania służb bezpieczeństwa ${ }^{6}$. Propozycja wydawania Iura Masoviae - bo taka była pierwotna nazwa projektu - była jednym z sygnałów odwilży postalinowskiej, która w środowisku historycznym dokonała się w latach 1955-1956, a jednym z jej beneficjentów stał się właśnie Jakub Sawicki ${ }^{7}$.

${ }^{1}$ Ius polonicum, codicibus veteribus manuscriptis et editionibus quibusque collatis, wyd. J.W. Bandtkie-Stężyński, Warszawa 1831, s. 365-472; Starodawne prawa polskiego pomniki, wyd. A.Z. Helcel, t. I, Kraków 1856, s. 265-300.

2 O. Balzer, Corpus Iuris Polonici medii aevii, Lwów 1891, s. 18 (ukazał się też jako artykuł, zob. „Kwartalnik Historyczny” 1891, t. 5, s. 50).

3 Średniowieczne prawa mazowieckiego pomniki z rękopisu petersburskiego, wyd. O. Balzer, ,Archiwum Komisyi Prawniczej”, t. V, Kraków 1897, s. 191-310 (wydawnictwo to ukazało się także jako samodzielna nadbitka z rokiem wydania 1895).

${ }^{4}$ W bibliografii prac Jakuba Sawickiego do 1956 r. jedyną pozycją odnoszącą się do Mazowsza była edycja statutów synodalnych diecezji płockiej wydana jako tom VI Concilia Poloniae. Por. F. Pasternak, Szkic biograficzny i bibliografia prac naukowych prof. Jakuba Sawickiego, „Prawo Kanoniczne” 1978, t. 21, z. 1-2, s. 203-210.

5 Na temat postaci i twórczości naukowej Jakuba Sawickiego zob. ibidem, s. 195-221; zob. też M. Sędek, Ch. Wójcik, Jakub Sawicki, „Czasopismo Prawno-Historyczne” 1981, t. 33, z. 1, s. 249-256; J. Senkowski, Sawicki Jakub (Jakób) Teodor Walery [w:] Polski Stownik Biograficzny, t. 35, Warszawa-Kraków 1994, s. 313-316; G. Bałtruszajtys, Jakub Sawicki 1899-1979 [w:] Profesorowie Wydziału Prawa i Administracji Uniwersytetu Warszawskiego 1808-2008, red. G. Bałtruszajtys, Warszawa 2008, s. 184-187; A. Zakrzewski, Jakub Sawicki 1899-1979 [w:] Portrety uczonych. Profesorowie Uniwersytetu Warszawskiego po 1945. S-Ż, red. W. Baraniewski, W. Tygielski, A.K. Wróblewski, Warszawa 2016, s. 48-55.

${ }^{6}$ Prowadzenie rozpoznania Jakuba Sawickiego było głównym zadaniem operacyjnym zwerbowanego przez Urząd Bezpieczeństwa w 1950 r. Zygmunta Kolankowskiego (TW Zyg). A. Kulecka, T.P. Rutkowski, Oczami agenta. Środowiska naukowe i archiwalne $w$ doniesieniach TW „Zyg”-Zygmunta Kolankowskiego, Warszawa 2012, s. 27, 59.

7 Szczególnie widoczna zmiana nastąpiła w 1956 r.: jesienią został on powołany na stanowisko wiceprezesa Polskiego Towarzystwa Historycznego oraz objął funkcję prodziekana Wydziału Prawa i Administracji UW. Zob. J. Senkowski, Sawicki..., s. 315. Szerzej o przełomie w naukach i środowisku historycznym: T.P. Rutkowski, Nauki historyczne $w$ Polsce w latach 1944-1970. Zagadnienia polityczne i organizacyjne, Warszawa 2009, s. 272-316 (o przywróceniu możliwości podejmowania działań naukowych i dydaktycznych szykanowanym wcześniej uczonym, w tym Jakubowi Sawickiemu zob. ibidem, s. 305-306).

Artykuły - Articles 
Na konferencji edytorskiej Komisji Wydawnictw Źródłowych INP PAN, która odbyła się w Krakowie w dniach 18-20 czerwca 1956 r. Jakub Sawicki przedstawił projekt wydawniczy Iura Masoviae ${ }^{8}$. Podstawowym założeniem wydania było objęcie nim pomników ziemskiego stanowionego prawa mazowieckiego w okresie jego odrębności. Zakres chronologiczny początkowo ustalono na lata 1320-1577, czyli od zjednoczenia Królestwa Polskiego - co stanowić miało cezurę odrębności prawa mazowieckiego wobec koronnego - aż do zatwierdzenia przez Stefana Batorego przyjęcia przez szlachtę województwa mazowieckiego prawa koronnego z zachowaniem niewielkiej części dotychczasowych zwyczajów w postaci tzw. Eksceptów mazowieckich ${ }^{9}$. Zakres terytorialny objął ziemie tworzące historycznie Księstwo Mazowieckie, a więc wchodzące następnie w skład województw: rawskiego, płockiego i mazowieckiego - do momentu obowiązywania w nich prawa mazowieckiego. Jeśli zaś chodzi o zakres rzeczowy, Sawicki przyjął następujące kryteria:

Wszystkie akty normatywne natury ogólnej i jednostkowej, dotyczące zarówno wewnętrznych, jak i zewnętrznych stosunków prawnych Mazowsza jako całości (od 1526) i poszczególnych jego ziem, bez względu na to, czy pochodzą od lokalnej władzy (książęta mazowieccy, wiece sądowe, sejmy i sejmiki mazowieckie) lub posiadają charakter skądinąd lokalny (spisy prawa zwyczajowego, lauda itp.) czy też pochodzą od władzy centralnej (król, sejm koronny) ze specjalnym przeznaczeniem dla Mazowsza jako całości (od 1526) lub dla którejś z jego ziem ${ }^{10}$.

Obejmował on zatem - oprócz prawa mazowieckiego stanowionego przez władców, sejmy i sejmiki - również akty o charakterze międzypaństwowym. Założenia te poddano pod dyskusję, po której wprowadzono pewne korekty. Przede wszystkim Sawicki zdawał sobie sprawę z pewnej sztuczności terminu a quo i zostawił tę kwestię do dalszych rozważań. Zmieniono nazwę na Iura Masoviae Terrestria, by podkreślić, że planowane wydawnictwo dotyczyć będzie prawa ziemskiego. Wreszcie postanowiono też dołączyć ugody normujące stosunki kościoła i władzy świeckiej (dotyczące np. dziesięcin, ius spolii, sytuacji chłopów w dobrach kościelnych) ${ }^{11}$.

Projekt wydawnictwa Iura Masoviae uzyskał w 1956 r. wsparcie finansowe ze strony PAN, co pozwoliło na sformowanie zespołu przygotowującego akty do wydania ${ }^{12}$. Jego kierownikiem został oczywiście Sawicki, a skład ostatecznie stanowiła przede

${ }^{8}$ Referat Jakuba Sawickiego zachowany jest w jego materiałach przechowywanych w Archiwum Polskiej Akademii Nauk. APAN, III-236, sygn. 114, k. 75-97. Jego podstawowe tezy oraz późniejszą dyskusję zreferował Stanisław Grodziski w sprawozdaniu z tej konferencji zamieszczonym w „Czasopiśmie Prawno-Historycznym" 1957, t. 9, z. 1, s. 424-425.

${ }^{9}$ Akt ten nastąpił 10 czerwca 1577 r., choć same Ekscepta mazowieckie wydrukowano razem z konstytucjami sejmu koronacyjnego Stefana Batorego. Zob. VC, t. II, vol. 1, wyd. S. Grodziski, I. Dwornicka, W. Uruszczak, Warszawa 2005, s. 380-392. Szerzej na temat okoliczności przyjęcia i treści Eksceptów mazowieckich zob. K. Brześkiewicz, Ekscepta mazowieckie - geneza i zakres przedmiotowy, „Zeszyty Naukowe Filii Uniwersytetu Warszawskiego w Białymstoku” 1988, z. 61: „Prawo i Ekonomia”, t. 14, s. 7-55.

${ }^{10}$ APAN, III-236, sygn. 114, k. 76-77.

${ }^{11}$ Korekty te zawierał projekt wydawniczy z końca 1957 r. (ibidem, k. 35-41). Został spożytkowany w opublikowanym drukiem sprawozdaniu z badań. J. Sawicki, Prace przygotowawcze do publikacji pomników dawnego prawa mazowieckiego, „Przegląd Historyczny” 1958, t. 49, z. 1-2, s. 361-363.

${ }^{12} \mathrm{Z}$ kolei PAN zawarł umowę zlecenie $\mathrm{z}$ Instytutem Historii Prawa UW na przeprowadzenie kwerendy źródłowej przez zespół badawczy. W 1957 r. z tego tytułu PAN przekazał kwotę 14 tys. złotych. APAN, III326, sygn. 114, k. 126.

Artykuły - Articles 
wszystkim grupa młodych pracowników naukowych: Bogdan Sobol, Hieronim Weiss, Janina Wejchertowa, Irena Sułkowska, Maria Woźniakowa (pracownicy Archiwum Głównego Akt Dawnych), Stanisław Russocki (Instytut Historii Prawa) oraz Elżbieta Sawicka, żona Jakuba Sawickiego, wspierająca go w wielu działaniach naukowych ${ }^{13}$. Zadaniem członków zespołu było prowadzenie kwerendy źródłowej z wykonaniem odpisów, stworzenie maszynopisów i ich kolacjonowanie. Prace posuwały się sprawnie; z opublikowanego na łamach „Przeglądu Historycznego” sprawozdania wynika, że już w 1958 r. ukończono kwerendę w Metryce Mazowieckiej, zbiorze Ignacego KapicyMilewskiego w Archiwum Głównym Akt Dawnych, przeprowadzono też większość kwerendy w Księgach grodzkich i ziemskich warszawskich i zakroczymskich. Łącznie zgromadzono już wówczas 437 tekstów do publikacji ${ }^{14}$. Niestety z końcem 1958 r. PAN - z bliżej nieznanych przyczyn - wstrzymał dalsze finansowanie projektu ${ }^{15}$. Od tego momentu prace toczyły się już w dużo wolniejszym tempie, co było pochodną braku środków na ich prowadzenie. W raporcie z postępów badań z wiosny 1960 r. Sawicki szczególnie skarżył się na niemożność pokrycia kosztów przepisywania na maszynie. Postęp prac według jego relacji wyglądał wówczas następująco: tom I - przygotowano kartotekę 257 tekstów, z czego 102 przepisano już na maszynie, ale wymagają jeszcze kolacjonowania; tom II - przygotowano kartotekę 200 tekstów, z czego przepisano na maszynie $58^{16}$. Pomimo tak znacznego zaawansowania projektu wydaje się, że wówczas wstrzymano dalsze nad nim prace. Rezultat działań z lat 1956-1960 można oceniać pozytywnie: właściwie zakończono kwerendę do tomu I oraz osiągnięto znaczący postęp w pracach redakcyjnych; w przypadku tomu II udało się pozyskać większość tekstów. Dodatkowym aspektem, o którym trzeba wspomnieć, był wzrost zainteresowania - dotychczas zaniedbaną - problematyką mazowiecką. Dzięki badaniom i publikacjom środowiska związanego z projektem osiągnięto znaczący postęp w stanie badań nad mazowieckim ustrojem i prawem w średniowieczu ${ }^{17}$.

13 Ibidem, k. 11-18. Biogramy niektórych członków zespołu zob. J. Grabowski, Sobol Bogdan (19291999) [w:] Słownik biograficzny archiwistów polskich, t. III: 1835-2015, red. E. Rosowska, Warszawa 2017, s. 220-221, H. Wajs, Sułkowska-Kuraś Irena Jadwiga (1917-2006) [w:] Stownik biograficzny archiwistów polskich, t. III: 1835-2015, red. E. Rosowska, s. 231-232; Stanisław Russocki - badacz dziejów i prawa. W 45-lecie pracy naukowej, red. H. Dziewanowska, Warszawa 1999.

14 J. Sawicki, Prace..., s. 367-368.

15 APAN, III-326, sygn. 114, k. 60.

${ }^{16}$ Ibidem, k. 60-61.

17 Okres 1956-1968 można wręcz nazwać złotą dekadą w badaniach nad ustrojem i prawem średniowiecznego Mazowsza. Powstały wówczas pod kierunkiem Jakuba Sawickiego trzy bardzo wartościowe doktoraty: S. Russocki, Formy władania ziemia w prawie ziemskim Mazowsza (koniec XIV-połowa XVI wieku), Warszawa 1961; J. Senkowski, Skarbowość Mazowsza od końca XIV wieku do 1526 roku, Warszawa 1965; B. Sobol, Sejm i sejmiki ziemskie na Mazowszu książecym, Warszawa 1968. Dodatkowo badacze związani z projektem opublikowali kilka cennych przyczynków, m.in.: S. Russocki, Z badań nad statutami książąt mazowieckich w XIV i XV wieku, „Czasopismo Prawno-Historyczne” 1956, t. 8, z. 2, s. 227-252; idem, Z dziejów prac przygotowawczych do ostatecznej redakcji zwodu prawa mazowieckiego z 1540 r., CPH 1957 , t. 9, z. 1, s. 4-28; idem, Mazowieckie rody gniazdowe. Kilka uwag na temat ich genezy i charakteru, PH 1961, t. 52, z. 1, s. 1-11; B. Sobol, O podstawie prawnej stosowania statutów i zwyczajów sądowych na Mazowszu w latach 1532-1540, CPH 1957, t. 9, z. 1, s. 45-74; idem, Sprawa sankcji zbioru Prażmowskiego w nieznanej zapisce sądowej z 1542 r., CPH 1958, t. X, z. 1, s. 79-90; idem, Ostatnie statuty mazowieckie z lat 1525 i 1526, PH 1958, t. 49, z. 2, s. 278-295.

Artykuły - Articles 
Do projektu edycji Iura Masoviae Terrestria powrócono pod koniec lat 60. XX w. przy zachęcie i wsparciu Bogusława Leśnodorskiego ${ }^{18}$. Impulsem do podjęcia działań było utworzenie w 1967 r. z inicjatywy Stanisława Herbsta Mazowieckiego Ośrodka Badań Naukowych (MOBN) przy Mazowieckim Towarzystwie Kultury, w skład którego wszedł również Sawicki ${ }^{19}$. W 1969 r. MOBN podjął się sfinansowania dokończenia prac i wydania pomników prawa mazowieckiego ${ }^{20}$. Po kilku miesiącach prac prowadzonych przy udziale Marii Woźniakowej, Jerzego Senkowskiego i Marka Sędka Sawicki przedstawił wiosną 1970 r. nowy projekt wydawniczy Iura Masoviae Terrestria. Tym razem zapadła decyzja, aby zakres chronologiczny cofnąć do ok. 1232 r., czyli do pierwszych zachowanych aktów prawnych wydanych przez Konrada księcia mazowieckie$\mathrm{go}^{21}$. Zdecydowano się wyłączyć $\mathrm{z}$ wydawnictwa akta dotyczące stosunków księstw mazowieckich z państwem zakonnym. Dodatkowo uwzględniono za to akty o typie międzypaństwowym odnoszące się do czasowego posiadania przez książąt mazowieckich części ziem ruskich. Edycja miała objąć dwa tomy: I - za lata 1232-1526 (258 pozycji); II - za lata 1527-1577 (240 pozycji). Jak zatem można zauważyć, zawartość tomu pierwszego pozostała niemal bez zmian w porównaniu z pracami zakończonymi kilka lat wcześniej, a planowany drugi tom powiększył się o ok. 40 aktów. Tomy podzielono dla celów wydawniczych na dwie części. Projektowano także dodatkowy wolumin, liczący 10-15 arkuszy wydawniczych, z polskimi thumaczeniami prawa mazowieckiego z XV i XVI w., który miałby się ukazać jako część 3 tomu II. Tam też miały znaleźć się indeksy, bibliografia i tablice synoptyczne II Zwodu prawa mazowieckiego z $1540 \mathrm{r}$. (tzw. Zwodu Goryńskiego) ${ }^{22}$. Dzięki pozyskanym środkom w pierwszej kolejności udało się dokończyć edycję całości tomu I, który został złożony do druku w Państwowym Wydawnictwie Naukowym jeszcze w 1970 r. Nie skończyło to jednak perypetii związanych z wydaniem pomników prawa mazowieckiego. Sawicki na początku 1971 r. został poproszony o przybycie do redakcji Polskiego Wydawnictwa Naukowego, gdzie poinformowano go, że kolegium redakcyjne zdecydowało o zdjęciu tomu I z programu wydawniczego na rok 1971. Przyczyną takiego stanu rzeczy miało być przekonanie kolegium, że „teksty źródłowe nie są tak ważne i potrzebne”. Reakcja Sawickiego - który większość swoich działań naukowych skupiał na edycji źródeł - była nietrudna do przewidzenia. „Wyraziłem swoje oburzenie na ten nowy przejaw głupoty i ciemniactwa” - odnotował w notatce sporządzonej ze spotkania w redakcji PWN ${ }^{23}$. Ostatecznie Iura Masoviae Terrestria zaczęło się ukazywać od roku 1972, po kilkunastu latach od rozpoczęcia prac nad tym projektem. Względy wydawnicze spowodowały zmianę planowanej numeracji: każda z części miała być wydawana jako odrębny tom. Łącznie więc zaplanowano opublikowanie pięciu tomów. Drukiem ukazały się tomy I-III, odpowiadające

${ }^{18}$ APAN, III-236, sygn. 261, k. 17.

${ }_{19}$ W. Makarczyk, Sprawozdanie z działalności Mazowieckiego Towarzystwa Kultury tacznie z Mazowieckim Ośrodkiem Badań Naukowych w 1967 r., „Rocznik Mazowiecki” 1969, t. 2, s. 441-444.

${ }^{20}$ Od połowy 1969 r. zaczęto wypłacać pewne środki na kolacjonowanie zebranych maszynopisów, APAN, III-236, sygn. 261, k. 43.

${ }^{21}$ Ostatecznie Iura Masoviae Terrestria zaczyna się od sześciu statutów tego władcy, z czego najwcześniejszy datowany jest na ok. $1228 \mathrm{r}$.

${ }^{22}$ APAN, III-236, sygn. 261, k. 28-30; por. też Iura Masoviae Terrestria, wyd. J. Sawicki, t. I: (12281471), Warszawa 1972, s. VII-X.

${ }^{23}$ APAN, III-236, sygn. 261, k. 16-17.

Artykuły - Articles 
pierwotnemu tomowi I (łącznie opublikowano 257 aktów i 3 dodatki) oraz pierwszej części tomu II (do roku 1540 - łącznie obejmuje on akty do numeru 363, przy czym ten ostatni stanowi edycję krytyczną II Zwodu mazowieckiego) ${ }^{24}$. Prace edytorskie zostały przerwane na początku 1974 r. - z tego okresu pochodzą najpóźniejsze adnotacje o kolacjonowaniu maszynopisów ${ }^{25}$. Przyczyna zaprzestania dalszych prac leżała w sferze osobistej - najpierw śmierć Elżbiety Sawickiej, a potem pogłębiająca się choroba Jakuba Sawickiego uniemożliwiły kontynuowanie tego dzieła ${ }^{26}$. Projekt dokończenia edycji podjął pod koniec lat 80. Krzysztof Brześkiewicz, uczeń Stanisława Russockiego, ale jego nagła i przedwczesna śmierć udaremniła te plany ${ }^{27}$.

W spuściźnie naukowej Sawickiego, przechowywanej w Archiwum PAN w Warszawie, znajduje się kartoteka przygotowywanego do wydania tomu IV Iura Masoviae Terrestria. Obecnie jest ona podzielona na cztery jednostki archiwalne ${ }^{28}$. Zawiera akty z lat $1541-$ 1576 o numerach od 364 do 472, przy czym numeracja nie zachowuje ciągłości - łącznie zgromadzono 76 aktów. Bardziej zaawansowana pod względem edytorskim jest pierwsza część zbioru z materiałami z lat 40. i 50. XVI w. Kartoteka w tym przypadku jest gotowa do wydania - każda jednostka składa się z metryczki z opisem źródła i podstawą edycji, odpisem źródła oraz dwoma maszynopisami zawierającymi tekst z aparatem naukowym - przed i po skolacjonowaniu. Jest też niewiele opuszczeń: brakuje tylko siedmiu aktów z numeracji 364-416 $6^{29}$. W drugiej części materiałów obok aktów przygotowanych do wydania znajdują się też maszynopisy przed kolacjonowaniem oraz akty zawierające sam odpis źródła z metryczką ${ }^{30}$. Jeśli chodzi o zakres rzeczowy, to kartoteka zawiera przede wszystkim: mandaty i uniwersały królewskie, zarządzenia urzędników mazowieckich - głównie vicesgerensa, postanowienia sejmów, sejmików i zjazdów o ile zawierają generalne normy prawne. Pierwotne założenie wyłączało akty prawa o charakterze indywidualnym, w tym nominacje na urzędy i wybór funkcje - stąd też tego typu materiałów nie uwzględniano przy tworzeniu kartoteki. W materiałach jest też kilka aktów przygotowanych do wydania, ale w stosunku do nich ostatecznie podjęto decyzję o wykreśleniu z zawartości planowanego tomu ${ }^{31}$. Pojawił się tam także - uwzględniony w ostatecznych planach - mandat Zygmunta Augusta do starosty płockiego Andrzeja

${ }^{24}$ Iura Masoviae Terrestria, t. I...; t. II: (1471-1526), Warszawa 1973; t. III: (1527-1540), Warszawa 1974.

25 APAN, III-236, sygn. 267, passim.

26 J. Senkowski, Sawicki..., s. 316. Pod koniec życia J. Sawicki oddał też pieczę nad opracowywaniem bibliografii historycznoprawnej. Zob. J. Sawicki, H. Izdebski, Materiały do polskiej bibliografii historyczno-prawnej za rok 1977, CPH 1979, t. 31, z. 1, s. 253.

27 A. Nowakowski, Wstęp [w:] Szkice z dziejów ustroju i prawa Polski. In memoriam dr Krzysztof Brześkiewicz, red. A. Nowakowski, Rzeszów 2006, s. 7.

28 APAN, III-236, sygn. 264-267. Krzysztof Brześkiewicz, korzystający z tych materiałów podczas przygotowywania doktoratu w latach 80 . miał do czynienia jeszcze z dwoma pudłami tekturowymi zawierającymi materiały do tomu IV (K. Brześkiewicz, Mazowsze pod rzadem koronnym w latach 1526-1577. Studium prawno-historyczne, maszynopis pracy doktorskiej na Wydziale Prawa i Administracji UW, Warszawa 1985, s. 38, przyp. 140). W ostatnich latach papiery po Jakubie Sawickim zostały uporządkowane, co spowodowało też zmianę w podziale i numeracji jednostek aktowych w zespole.

29 APAN, III-236, sygn. 264, 265, passim.

30 Odpisy: APAN, III-236, sygn. 266, nr. 426, 427, 429, 430, 440, 441; sygn. 267, nr 455.

31 Są to np.: protestacja vicesgerensa dotycząca wyboru posłów ziemi warszawskiej na sejm mazowiecki w 1553 r. (ibidem, sygn. 265, nr 398, pierwotnie); uniwersał królewski z 1563 r. zwołujący sejmiki zakroczymski i generalny mazowiecki (ibidem, sygn. 266); uniwersał vicesgerensa zwołujący zjazd szlachty 
Sieprskiego z 1559 r., dotyczący respektowania dawnych praw wojskich płockich do pobierania dochodów z ceł wodnych ${ }^{32}$ - prawdopodobnie potraktowany przez Sawickiego jako relikt dawnego prawa mazowieckiego. To - wraz z wyłączeniami aktów przy ostatecznej redakcji - pokazuje obiektywne trudności w doborze akt z XVI w. do edycji. Sądzić można, że problem jest ogólniejszy - zasady doboru, które bardzo dobrze sprawdzały się przy prawie średniowiecznym, nieco zawodzą $\mathrm{w}$ zderzeniu $\mathrm{z}$ realiami rozwoju parlamentaryzmu szlacheckiego w XVI w. Pojawiają się nowe problematyczne kwestie: Czy funkcje elekcyjne wykonywane przez sejmik (zwłaszcza wybór posłów, poborców podatkowych) należy traktować jako akty indywidualne, odnoszące się tylko do osób sprawujących dane funkcje, czy też - jednak - jako mające charakter generalny? Trzeba pamiętać, że przedstawiciele reprezentowali szlachtę ziemi w parlamencie i tam przedstawiali jej postulaty oraz mieli wpływ na prawodawstwo - w także na partykularne. Jak traktować uniwersały zwołujące sejmiki i zjazdy szlacheckie? Czy uchwały zjazdów szlacheckich uznawać za źródło prawa lokalnego?

Dokończenie edycji Iura Masoviae Terrestria wymagać będzie odpowiedzi na powyższe pytania, jak również namysłu nad zakresem samego wydania ${ }^{33}$. Nawet już na wstępnym etapie przygotowania takiej edycji można stwierdzić, że powinna ona uwzględniać następujące elementy:

1. Reedycja pierwszych trzech tomów wraz z opatrzeniem ich pełnym aparatem naukowym: indeksami, przypisami rzeczowymi i bibliografią. Zwłaszcza brak indeksów dla tomów I-III (tom V z indeksami nie wyszedł poza sferę wstępnych planów) utrudnia korzystanie z pierwszego wydania pomników prawa mazowieckiego. Należy też porównać pierwsze wydanie z późniejszymi edycjami źródłowymi z zakresu prawa mazowieckiego ${ }^{34}$. Dodatkowo bardzo przydatna byłaby edycja elektroniczna: utworzenie bazy danych z multiwyszukiwarką. W tym aspekcie niezmiernie przydatna mogłaby być publikacja z wykorzystaniem infrastruktury tworzonej przez Macieja Mikułę nowej bazy pod nazwą IURA. Źródta prawa dawnego.

2. Dokończenie prac redakcyjnych nad tomem IV, przygotowanym przez Sawickiego i jego publikacja - tradycyjna i elektroniczna - wraz z aparatem naukowym. Realizując to zadanie, należy spróbować odnaleźć akty, których dotyczyły brakujące numery w kartotece (ok. $30 \%$ całości planowanego wydania).

3. Kontynuacja wydania tomu Iura Masoviae Terrestria z okresu 1540-1577. Z metryczek aktów zawartych w kartotece wynika, że kwerenda przeprowadzona na potrzeby wydania tomu IV w Księgach grodzkich i ziemskich z terenów Mazowsza prawdopodobnie nie wyszła poza ramy, które zakreślono w sprawozdaniu z badań w 1958 r. Objęła

mazowieckiej w 1575 r. - przy czym w tomie IV zaplanowano wydanie uchwał tego zjazdu (ibidem, sygn. 267, nr 469).

32 Ibidem, sygn. 265, nr 416.

${ }^{33}$ Uwidoczniła to dyskusja po wygłoszonym referacie na - organizowanym przez Wydział Prawa i Administracji Uniwersytetu Jagiellońskiego - sympozjum „Łączą nas źródła”, które odbyło się 19 września 2019 r. w Krakowie. Szczególnie wdzięczny jestem za głosy prof. Wacława Uruszczaka i prof. Karola Łopateckiego.

${ }^{34}$ Nowy kodeks dyplomatyczny Mazowsza, cz. 2: Dokumenty z lat 1248-1355, wyd. I. Sułkowska-Kuraś, S. Kuraś, K. Pacuski, H. Wajs, Warszawa 1989; cz. 3: Dokumenty z lat 1356-1381, wyd. I. Sułkowska-Kuraś, S. Kuraś, Warszawa 2000; Metryka Koronna nr 8. Liber intitulatus: Varsavia Boleslai, Conradi, Janussii et Annae ducum Masoviae ab anno 1471 usque ad 1526, wyd. A. Salina, I. Stembrowicz, Warszawa 2018.

Artykuły - Articles 
ona zatem gruntowne przebadanie Ksiąg zakroczymskich oraz ziemi warszawskiej (warszawskich, tarczyńskich i błońskich). Jedynie pomocniczo prowadzono kwerendę w dobrze zachowanych zasobach ksiąg wyszogrodzkich i różańskich. Ze względu na to, że planowany tom IV obejmował np. lauda ustalające podatki lokalne, czy akty związane z działaniem lokalnego sądownictwa, rozszerzenie badań źródłowych w tym zakresie wydaje się w pełni uzasadnione. Odrębnym problemem jest kwerenda w Księgach grodzkich i ziemskich płockich. Relikty prawa mazowieckiego w województwie płockim dotyczyły nie tylko uposażenia wojskich: wskazać tu można m.in. utrzymywanie się jurysdykcji wojewody płockiego nad drobną szlachtą ${ }^{35}$ czy średniowieczne uposażenie kasztelanów: płockiego i raciąskiego z części dochodów starostwa płockiego ${ }^{36}$. Warto rozszerzyć kwerendę na całość zbioru Ignacego Kapicy-Milewskiego - nie tylko części znajdującej się w Archiwum Głównym Akt Dawnych w Warszawie, ale również w Krakowie, Kijowie i Drohiczynie. Odrębnym zagadnieniem jest konieczność uwzględnienia konstytucji sejmowych. Zabrakło ich w kartotece - pomimo umieszczenia ich w zakresie rzeczowym planowanego wydawnictwa - a zwłaszcza w latach 60 . i 70. XVI w. sejmy walne uchwalały akty prawne regulujące stosunki na Mazowszu ${ }^{37}$.

4. Uwzględnienie całości laudów sejmików partykularnych poszczególnych ziem i generalnego województwa mazowieckiego z lat 1526-1577, łącznie z instrukcjami poselskimi i uniwersałami zwołującymi sejmiki. Oznacza to rozszerzenie pojęcia aktów generalnych także na kwestie związane z funkcjonowaniem sejmików w systemie parlamentarnym. Materiały te można wydać jako odrębny tom Lauda Masoviensia.

5. Najbardziej dyskusyjną kwestią jest zmiana dotychczasowych ram rzeczowych ograniczających wydawnictwo tylko do funkcjonowania odrębnego prawa mazowieckiego. Jak już sygnalizowano, w praktyce może rodzić to pewne problemy związane z próbą śledzenia utrzymywania się reliktów dawnego prawa już po wprowadzeniu prawa koronnego. Być może zasadne byłoby rozszerzenie zakresu pojęciowego z prawa mazowieckiego na prawo lokalne Mazowsza. Umożliwiłoby to kontynuację wydawania aktów prawa lokalnego i laudów sejmikowych także po roku 1577. Pomysł jednak jest o tyle kontrowersyjny, że zmienia jedno z podstawowych założeń stojących u zarania edycji Iura Masoviae.

Podsumowując problematykę kontynuacji edycji Iura Masoviae Terrestria, podkreślić należy naukowe walory stojące za takim projektem. Pozwoli ona na dokończenia bardzo ważnej serii wydawniczej, i to u progu 500-lecia inkorporacji Mazowsza do Królestwa Polskiego. Umożliwi też - dzięki rozszerzeniu o materiały parlamentarne dokładniejszą analizę ciekawego zjawiska integracji Mazowsza z Koroną w wieku XVI, czego skutkiem było przekształcenie sejmu mazowieckiego w sejmik generalny z włączeniem reprezentacji parlamentarnej regionu w prace sejmu walnego oraz - w osta-

35 Na ten temat: A. Wolff, Studia nad urzędnikami mazowieckimi 1370-1526, Wrocław 1962, s. 85-93; A. Moniuszko, Relikt sądownictwa średniowiecznego - o jurysdykcji wojewody płockiego nad szlachta w potowie XVII w., „Zeszyty Prawnicze” 2011, t. 11. z. 2, s. 317-336.

36 Wspominała o tym instrukcja poselska uchwalona na sejmiku raciąskim w 1589 r. AGAD, t. 17, k. 75v.

37 Tytułem przykładu można wskazać reformę mazowieckiego wymiaru sprawiedliwości przeprowadzoną przez sejm w 1565 r.: konstytucje Sądy grodzkie mazowieczkie; Ukrocenie postępu prawnego na Mazowszu; Sąy grodzkie wąsoskie, zembrowskie i ostrowskie; Pisarstwa ziemskie nurskie i zembrowskie etc.; Podkomorstwo różańskie. VC, t. II, vol. 1, s. 175-176.

Artykuły - Articles 
teczności - przyjęcie prawa koronnego ${ }^{38}$. Pozwoli także na reedycję pierwszych trzech tomów z uzupełnionym aparatem naukowym i ich cyfryzację. Będzie wreszcie hołdem dla Profesora Jakuba Sawickiego, dokończeniem jego dzieła, nad którym zaczął prace ponad 60 lat temu ${ }^{39}$.

\section{Bibliografia}

\section{Źródła rękopiśmienne}

Archiwum Główne Akt Dawnych w Warszawie, Księgi grodzkie wieczyste wyszogrodzkie, t. 17. Archiwum Polskiej Akademii Nauk w Warszawie, III-236, sygn. 114, 261, 264-267.

\section{Źródła wydane}

Iura Masoviae Terrestria, wyd. J. Sawicki, t. I-III, Warszawa 1972-1974.

Ius polonicum, codicibus veteribus manuscriptis et editionibus quibusque collatis, wyd. J.W. Bandtkie-Stężyński, Warszawa 1831.

Metryka Koronna $\mathrm{nr}$ 8. Liber intitulatus: Varsavia Boleslai, Conradi, Janussii et Annae ducum Masoviae ab anno 1471 usque ad 1526, wyd. A. Salina, I. Stembrowicz, Warszawa 2018.

Nowy kodeks dyplomatyczny Mazowsza, cz. 2: Dokumenty z lat 1248-1355, wyd. I. Sułkowska-Kuraś, S. Kuraś, K. Pacuski, H. Wajs, Warszawa 1989; cz. 3: Dokumenty z lat 1356-1381, wyd. I. Sułkowska-Kuraś, S. Kuraś, Warszawa 2000.

Starodawne prawa polskiego pomniki, wyd. A.Z. Helcel, t. I, Kraków 1856.

Średniowieczne prawa mazowieckiego pomniki z rękopisu petersburskiego, wyd. O. Balzer, Archiwum Komisyi Prawniczej, t. V, Kraków 1897.

Volumina Constitutionum, t. II, vol. 1, wyd. S. Grodziski, I. Dwornicka, W. Uruszczak, Warszawa 2005.

\section{Opracowania}

Balzer O., Corpus Iuris Polonici medii aevii, Lwów 1891 (nadbitka z: „Kwartalnik Historyczny”, 1891, t. 5, s. 314-358).

Bałtruszajtys G., Jakub Sawicki 1899-1979 [w:] Profesorowie Wydziału Prawa i Administracji Uniwersytetu Warszawskiego 1808-2008, red. G. Bałtruszajtys, Warszawa 2008, s. 184-187.

Bardach J., Historia prawa na Uniwersytecie Warszawskim (1915-1988) [w:] J. Bardach, Themis a Clio czyli Prawo i historia, Warszawa 2001, s. 303-326.

\footnotetext{
${ }^{38} \mathrm{Na}$ temat procesów integracyjnych w tym okresie: J. Dzięgielewski, Życie polityczne na Mazowszu od schytku XV do polowy XVII wieku [w:] Dzieje Mazowsza, t. II: Lata 1527-1794, red. J. Tyszkiewicz, Pułtusk 2015, s. 46-73; J. Choińska-Mika, Mazowiecki parlamentaryzm XVI-XVII wieku [w:] ibidem, s. 116-138.

${ }^{39}$ W 1988 r. Juliusz Bardach podkreślił: „Publikacja pozostałych dwóch tomów, znacznie zaawansowanych, jest obowiązkiem środowiska, które Jakubowi Sawickiemu niemało zawdzięcza”. J. Bardach, Historia prawa na Uniwersytecie Warszawskim (1915-1988) [w:] J. Bardach, Themis a Clio czyli Prawo i historia, Warszawa 2001, s. 315.
} 
Brześkiewicz K., Ekscepta mazowieckie - geneza i zakres przedmiotowy, „Zeszyty Naukowe Filii Uniwersytetu Warszawskiego w Białymstoku” 1988, z. 61: „Prawo i Ekonomia”, t. 14, s. $7-55$.

Brześkiewicz K., Mazowsze pod rzadem koronnym w latach 1526-1577. Studium prawno-historyczne, maszynopis pracy doktorskiej na Wydziale Prawa i Administracji UW, Warszawa 1985.

Choińska-Mika J., Mazowiecki parlamentaryzm XVI-XVII wieku [w:] Dzieje Mazowsza, t. II: Lata 1527-1794, red. J. Tyszkiewicz, Pułtusk 2015, s. 116-168.

Dzięgielewski J., Życie polityczne na Mazowszu od schyłku XV do połowy XVII wieku [w:] Dzieje Mazowsza, t. II: Lata 1527-1794, red. J. Tyszkiewicz, Pułtusk 2015, s. 29-115.

Grabowski J., Sobol Bogdan (1929-1999) [w:] Słownik biograficzny archiwistów polskich, t. III: 1835-2015, red. E. Rosowska, Warszawa 2017, s. 220-221.

Grodziski S., Konferencja Komisji Redakcyjnej Wydawnictw Źródłowych Komitetu Nauk Prawnych Polskiej Akademii Nauk, CPH 1957, t. 9, z. 1, s. 424-428.

Kulecka A., Rutkowski T.P., Oczami agenta. Środowiska naukowe i archiwalne $w$ doniesieniach TW „Zyg”- Zygmunta Kolankowskiego, Warszawa 2012.

Makarczyk W., Sprawozdanie z działalności Mazowieckiego Towarzystwa Kultury łacznie z Mazowieckim Ośrodkiem Badań Naukowych w 1967 r., „Rocznik Mazowiecki” 1969, t. 2, s. 441-450.

Moniuszko A., Relikt sądownictwa średniowiecznego - o jurysdykcji wojewody płockiego nad szlachta w połowie XVII w., „Zeszyty Prawnicze” 2011, t. 11, z. 2, s. 317-336.

Pasternak F., Szkic biograficzny i bibliografia prac naukowych prof. Jakuba Sawickiego, „Prawo Kanoniczne" 1978, t. 21, z. 1-2, s. 195-221.

Russocki S., Formy władania ziemia w prawie ziemskim Mazowsza (koniec XIV-połowa XVI wieku), Warszawa 1961.

Russocki S., Mazowieckie rody gniazdowe. Kilka uwag na temat ich genezy i charakteru, PH 1961, t. 52, z. 1, s. 1-11.

Russocki S., Z badań nad statutami książą mazowieckich w XIV i XV wieku, CPH 1956, t. 8, z. 2, s. $227-252$.

Russocki S., Z dziejów prac przygotowawczych do ostatecznej redakcji zwodu prawa mazowieckiego z 1540 r., CPH 1957, t. 9, z. 1, s. 4-28.

Rutkowski T.P., Nauki historyczne w Polsce w latach 1944-1970. Zagadnienia polityczne i organizacyjne, Warszawa 2009.

Sawicki J., Izdebski H., Materiaty do polskiej bibliografii historyczno-prawnej za rok 1977, CPH 1979, t. 31, z. 1, s. 253-344.

Sawicki J., Prace przygotowawcze do publikacji pomników dawnego prawa mazowieckiego, $\mathrm{PH}$ 1958, t. 49, z. 1-2, s. 360-368.

Senkowski J., Sawicki Jakub (Jakób) Teodor Walery [w:] Polski Stownik Biograficzny, t. 35, Warszawa-Kraków 1994, s. 313-316.

Senkowski J., Skarbowość Mazowsza od końca XIV wieku do 1526 roku, Warszawa 1965.

Sędek M., Wójcik Ch., Jakub Sawicki, CPH 1981, t. 33, z. 1, s. 249-256.

Sobol B., O podstawie prawnej stosowania statutów i zwyczajów sądowych na Mazowszu w latach 1532-1540, CPH 1957, t. 9, z. 1, s. 45-74.

Sobol B., Ostatnie statuty mazowieckie z lat 1525 i 1526, PH 1958, t. 49, z. 2, s. 278-295.

Sobol B., Sejm i sejmiki ziemskie na Mazowszu książęcym, Warszawa 1968.

Sobol B., Sprawa sankcji zbioru Prażmowskiego w nieznanej zapisce sq̨dowej z 1542 r., CPH 1958 , t. 10, z. 1. s. 278-295.

Stanisław Russocki-badacz dziejów i prawa. W 45-lecie pracy naukowej, red. H. Dziewanowska, Warszawa 1999. 
Szkice z dziejów ustroju i prawa Polski. In memoriam dr Krzysztof Brześkiewicz, red. A. Nowakowski, Rzeszów 2006.

Wajs H., Sułkowska-Kuraś Irena Jadwiga (1917-2006) [w:] Słownik biograficzny archiwistów polskich, t. III: 1835-2015, red. E. Rosowska, Warszawa 2017, s. 231-232.

Wolff A., Studia nad urzędnikami mazowieckimi 1370-1526, Wrocław 1962.

Zakrzewski A., Jakub Sawicki 1899-1979 [w:] Portrety uczonych. Profesorowie Uniwersytetu Warszawskiego po 1945. S-Ż, red. W. Baraniewski, W. Tygielski, A.K. Wróblewski, Warszawa 2016, s. 48-55. 